\title{
DESIGNING WRISTBANDS AS A WALKING AID FOR THE ARDUINO NANO-BASED VISUALLY IMPAIRED
}

\author{
Budi Prijo Sembodo*, Moh. Thoyib \\ Department of Electrical Engineering \\ University of PGRI Adi Buana Surabaya \\ *Corresponding email address: pakyosembodo@gmail.com
}

\begin{abstract}
In the 4.0 era, walking aids for the visually impaired are needed, especially when the user is indoors and outdoors. There are already many tools created, one of which the author wants to make is a wristband. Components include: Ultrasonic Sensor HCSR04, Arduino Nano, Servo SG90 Motor, and Buzzer. The stages in this study are designing hardware, designing programs, and implementing and testing tools. The testing carried out on this tool is to read the results of objects with distances of $80 \mathrm{~cm}$, $90 \mathrm{~cm}, 100 \mathrm{~cm}, 110 \mathrm{~cm}$ and $120 \mathrm{~cm}$. Not only did it test the distance, it also tested the rotation angle performed by the servo motor to drive ultrasonic sensors by $0^{\circ}, 6^{\circ}$,and $120^{\circ}$. It aims to be able to detect in any direction. The results of this tool test have $a$ repeatability rate of $98 \%$, as well as a $97.33 \%$ success rate for detecting objects.
\end{abstract}

Keywords : wristband, ultrasonic sensor $\mathrm{HC}$ SR04, servo motor, visually impaired.

\section{INTRODUCTION}

People with visual disabilities need navigation aids to know the environment when going about their daily activities, especially when they are walking. For the visually impaired, of course this becomes an obstacle.

At this time, there are many technologies that are made specifically to help the visually impaired make it easier for them to do business. One example of a tool that has been created is a blind stick (Andreas, 2017). The way the tool works is when the ultrasonic sensor detects a hitch then the sensor sends a signal to the Arduino Nano microcontroller and a sound alert via buzzer. But the stick still has many drawbacks, namely the limitations in detection in one direction only, in addition if the stick falls will cause damage to the sensor.

Several similar studies were also conducted by Setyo et al in 2016 (Setyo, 2016) under the title Handsight : Hand Mounted Device to help the Ultrasonic and Arduinobased Blind. In this study, two HC-SR04 sensors were used as distance detection sensors on the front right and front left sides, two servo motors as indicators of obstructions on the right and left and a buzzer as sound indicators. This tool is in the form of gloves worn by the visually impaired. Other research also made walking aids in the form of electronic glasses (Muhammad Nur Meizani, 2015).

According to the background above the author wants to make a new innovation that is to turn the stick into a bracelet that is more efficient, can detect any direction, and not easily fall, and use the components of the tool more effectively and efficiently. It is equipped with HC-SR04 ultrasonic sensors, servo motors, and buzzer sound output.

\section{RESEARCH METHODS}

a. Research Stage

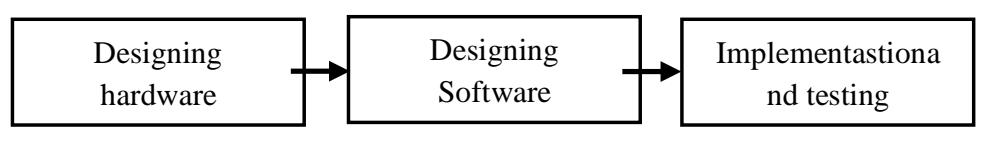

Figure 1. Research Stage 
BEST

Journal of Applied Electrical and Science Technology - University of PGRI Adi Buana

p-ISSN 2715-2871

e-ISSN 2714-5247

b. Flowchart

Here is a water chart (Flowchart) of the design and creation stages of the tool :

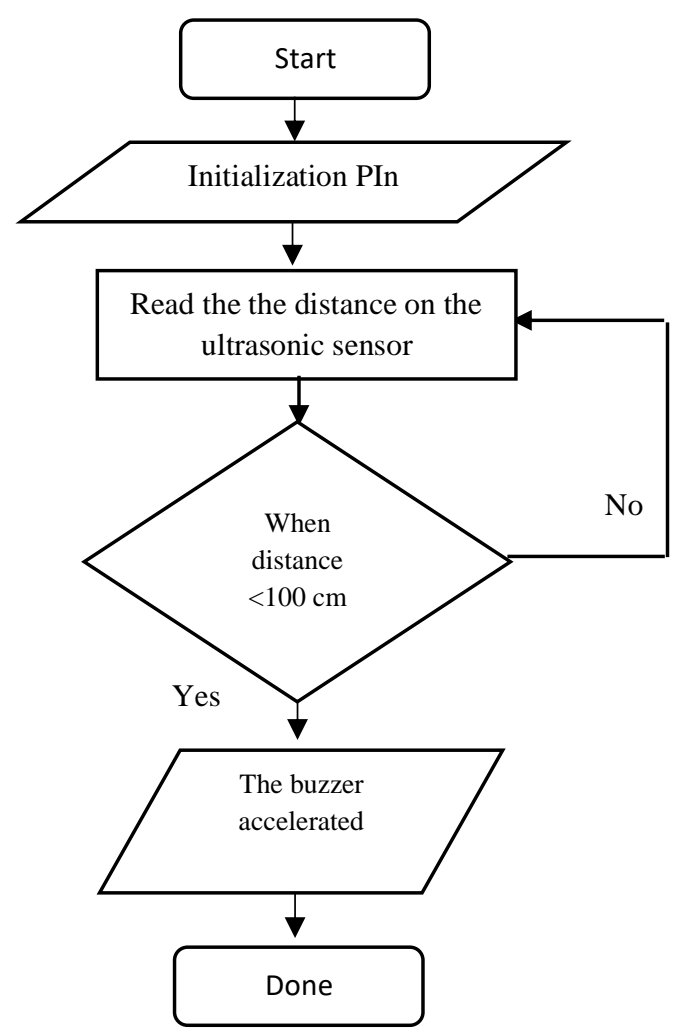

Figure 2. Distance Reading Program Flowchart via Ultrasonic Sensors

c. Product Range

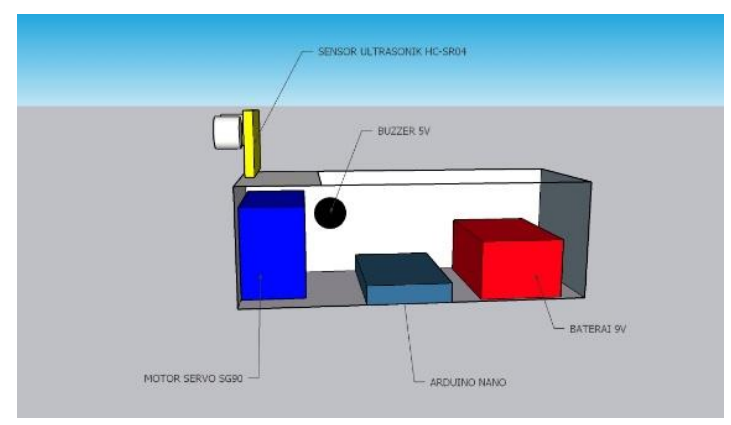

Figure 3. Product Range
Description:

1) Ultrasonic sensor as a distance sensor that can tell when there is an object in front of it.

2) Servo motor as the drive of the ultrasonic sensor in order to move from $0^{\circ}$ to $120^{\circ}$ so vice versa.

3) Buzzer as the output of the warning sound..

4) Arduino Nano as a working regulator of servo motors and ultrasonic sensors.

5) 9V battery as power.

d. Scope

The scope in this study is:

1) The range angle of the sensor in motion is $120^{\circ}$.

2) Testing objects at distances of $80 \mathrm{~cm}, 90 \mathrm{~cm}, 100 \mathrm{~cm}, 110 \mathrm{~cm}$, and $120 \mathrm{~cm}$.

3) Servo motor rotation angle testing of $0^{\circ}, 60^{\circ}$ and $120^{\circ}$

e. Component Materials

Table 1. Component Materials

\begin{tabular}{|l|l|l|}
\hline No. & Component N ame & Qty \\
\hline 1. & Arduino Nano & 1 piece \\
\hline 2. & $\begin{array}{l}\text { HC-SR04 Ultrasonic } \\
\text { Sensors }\end{array}$ & 1 piece \\
\hline 3. & Servo SG90 Bikes & 1 piece \\
\hline 4. & Buzzer 5 V & 1 piece \\
\hline 5. & 9 V Battery & 1 piece \\
\hline 6. & Socket Baterai 9 V & 1 piece \\
\hline 7. & Cable Jumper & To taste \\
\hline 8. & Switch & 1 piece \\
\hline 9. & Watch straps & 1 piece \\
\hline 11. & Black Box & \\
\hline & & \\
\hline
\end{tabular}




\section{A. Variables and Definitions of Variable Operations}

The free variable in this study was the Ultrasonic Sensor. The Operational Definition of Free Variables is a wristband that can be used by the visually impaired to help with indoor and outdoor walking.

A variable tied to this study is the ability of sensors to detect distances with objects in front of them. While the Variable Operational Definition of a bound variable is when the wristband approaches the object then the buzzer will sound, so as to warn the visually impaired not to crash into the object.

\section{B. Data Analysis Method}

The method of data collection used is the observation method and documentation used to observe the results of the trial and study the references related to the design of the tool. While as a method of data analysis is a descriptive analysis method that describes the results of trials include:

a. Ultrasonic sensor trial results, used to measure distance and detect objects in front of them. b. Test the ability of Arduino nano as a servo motor processor and ultrasonic sensor.

c. Buzzer as a tool output when it detects an object that is in front of it.

\section{RESULTS AND DISCUSSIONS}

In this section is discussed about testing based on the planning of the system created. Testing is carried out to find out how the system works and to see if the device is in line with planning. After the stage of making wristbands as a walking aid for the visually impaired is completed, then the next stage is the testing phase of the tool.

As for testing data and precision (Repeatability) at angles $0^{\circ}, 60^{\circ}$ and $120^{\circ}$. in the simulation experiment are as follows:

Table 2. Tool test data with distance variation at angle $0^{\circ}$

\begin{tabular}{|c|c|c|c|c|c|c|c|c|c|c|}
\hline \multirow{2}{*}{ No. } & \multirow{2}{*}{$\begin{array}{l}\text { Distance } \\
(\mathrm{cm})\end{array}$} & \multicolumn{5}{|c|}{ Repetition to $-(\mathrm{cm})$} & \multirow{2}{*}{$\begin{array}{l}\text { Largest } \\
\text { distance } \\
(\mathrm{cm})\end{array}$} & \multirow{2}{*}{$\begin{array}{l}\text { Smallest } \\
\text { distance } \\
(\mathrm{cm})\end{array}$} & \multirow{2}{*}{$\begin{array}{l}\text { Average } \\
\text { distance } \\
(\mathrm{cm})\end{array}$} & \multirow{2}{*}{$\begin{array}{l}\text { Largest } \\
\text { distance- } \\
\text { smallest } \\
\text { distance }(\mathrm{cm})\end{array}$} \\
\hline & & 1 & 2 & 3 & 4 & 5 & & & & \\
\hline 1. & 80 & 80 & 79 & 79 & 79 & 79 & 80 & 79 & 79,2 & 1 \\
\hline 2. & 90 & 89 & 87 & $\begin{array}{l}89 \\
\end{array}$ & 87 & 88 & 87 & 89 & 88 & 2 \\
\hline 3. & 100 & 97 & 96 & 96 & 97 & 98 & 97 & 99 & 96,8 & 2 \\
\hline 4. & 110 & 105 & 106 & 105 & 106 & 106 & 105 & 107 & 105,6 & 2 \\
\hline 5. & 120 & 116 & 117 & 117 & 117 & 118 & 117 & 119 & 116,2 & 2 \\
\hline
\end{tabular}

The precision value at angle $0^{\circ}$ is as follows: (Morris and Langari, 2012)

Precisiom (Repeatability)

$$
\begin{aligned}
\delta & =\frac{\Delta}{F S} \times 100 \% \\
& =\frac{2}{100} \times 100 \% \\
& =2 \%
\end{aligned}
$$

$$
\begin{aligned}
\text { Repeatability } & =100 \%-\delta \\
& =100 \%-2 \% \\
& =98 \%
\end{aligned}
$$


Journal of Applied Electrical and Science Technology - University of PGRI Adi Buana

Table 3. Tool testing data with distance variation at $60^{\circ}$ angle

\begin{tabular}{|c|c|c|c|c|c|c|c|c|c|c|}
\hline \multirow[b]{2}{*}{ No. } & \multirow{2}{*}{$\begin{array}{l}\text { Distance } \\
(\mathrm{cm})\end{array}$} & \multicolumn{5}{|c|}{ Repetation to $-(\mathrm{cm})$} & \multirow{2}{*}{$\begin{array}{l}\text { Largest } \\
\text { distance } \\
(\mathrm{cm})\end{array}$} & \multirow{2}{*}{$\begin{array}{l}\text { Smallest } \\
\text { distance } \\
(\mathrm{cm})\end{array}$} & \multirow{2}{*}{$\begin{array}{l}\text { Average } \\
\text { distance } \\
(\mathrm{cm})\end{array}$} & \multirow{2}{*}{$\begin{array}{l}\text { Largest } \\
\text { distance } \\
\text { smallest } \\
\text { distance }(\mathrm{cm})\end{array}$} \\
\hline & & 1 & 2 & 3 & 4 & 5 & & & & \\
\hline 1. & 80 & 78 & 79 & 77 & 79 & 77 & 79 & 77 & 78 & 2 \\
\hline 2. & 90 & 88 & 87 & 88 & 87 & 89 & 87 & 89 & 87,8 & 2 \\
\hline 3. & 100 & 97 & 99 & 98 & 97 & 98 & 97 & 99 & 97,8 & 2 \\
\hline 4. & 110 & 104 & 105 & 106 & 105 & 106 & 104 & 105 & 105,2 & 2 \\
\hline 5. & 120 & 117 & 117 & 117 & 116 & 118 & 116 & 118 & 117 & 2 \\
\hline
\end{tabular}

The precision value at angle $60^{\circ}$ is as follows: :

Precision (Repeatability)

$$
\begin{aligned}
\delta & =\frac{\Delta}{F S} \times 100 \% \\
& =\frac{2}{100} \times 100 \% \\
& =2 \%
\end{aligned}
$$

\begin{tabular}{|c|c|c|c|c|c|c|c|c|c|c|}
\hline \multirow[b]{2}{*}{ No. } & \multirow{2}{*}{$\begin{array}{c}\text { Distance } \\
(\mathrm{cm})\end{array}$} & \multicolumn{5}{|c|}{ Repetition to $-(\mathrm{cm})$} & \multirow{2}{*}{$\begin{array}{l}\text { Largest } \\
\text { distance } \\
(\mathrm{cm})\end{array}$} & \multirow{2}{*}{$\begin{array}{l}\text { Smallest } \\
\text { distance } \\
(\mathrm{cm})\end{array}$} & \multirow{2}{*}{$\begin{array}{l}\text { Average } \\
\text { distance } \\
(\mathrm{cm})\end{array}$} & \multirow{2}{*}{$\begin{array}{l}\text { Largest } \\
\text { distance - } \\
\text { smallest } \\
\text { distance }(\mathrm{cm})\end{array}$} \\
\hline & & 1 & 2 & 3 & 4 & 5 & & & & \\
\hline 1. & 80 & 77 & 79 & 78 & 77 & 78 & 79 & 77 & 77,8 & 2 \\
\hline 2. & 90 & 87 & 87 & 87 & 88 & 89 & 88 & 87 & 87,6 & 2 \\
\hline 3. & 100 & 97 & 98 & 97 & 97 & 98 & 98 & 97 & 97,4 & 2 \\
\hline 4. & 110 & 107 & 105 & 105 & 106 & 106 & 107 & 105 & 105,8 & 2 \\
\hline 5. & 120 & 118 & 117 & 118 & 116 & 117 & 118 & 116 & 117,2 & 2 \\
\hline
\end{tabular}

$$
\begin{aligned}
\text { Repeatability } & =100 \%-\delta \\
& =100 \%-2 \% \\
& =98 \%
\end{aligned}
$$

Table 4. Tool testing data with distance variation at angle $120^{\circ}$

The precision value at angle $120^{\circ}$ is as follows: :

Precisiom (Repeatability)

$$
\begin{aligned}
\delta & =\frac{\Delta}{F S} \times 100 \% \\
& =\frac{2}{100} \times 100 \% \\
& =2 \%
\end{aligned}
$$




$$
\begin{aligned}
\text { Repeatability }= & 100 \%-\delta \\
& =100 \%-2 \% \\
& =98 \%
\end{aligned}
$$

After finding Precision (Repeatability), then the author will calculate the average of precision (Repeatability) with the following calculations: :

$$
\begin{aligned}
& \text { Average repeatability }=\frac{\text { srepeatability }}{n} \\
& \qquad=\frac{98 \%+98 \%+98 \%}{3} \\
& =98 \%
\end{aligned}
$$

The authors will also take

\begin{tabular}{|c|c|c|c|c|c|c|c|c|c|c|c|}
\hline \multirow{2}{*}{ No. } & \multirow{2}{*}{ Distance } & \multicolumn{10}{|c|}{ Testing to - } \\
\hline & & 1 & 2 & 3 & 4 & 5 & 6 & 7 & 8 & 9 & 10 \\
\hline 1. & 80 & $\sqrt{ }$ & $\sqrt{ }$ & $\sqrt{ }$ & $\sqrt{ }$ & $\sqrt{ }$ & $\sqrt{ }$ & $\sqrt{ }$ & $\sqrt{ }$ & $\sqrt{ }$ & $\sqrt{ }$ \\
\hline 2. & 90 & $\sqrt{ }$ & $\sqrt{ }$ & $\sqrt{ }$ & $\sqrt{ }$ & $\sqrt{ }$ & $\sqrt{ }$ & $\sqrt{ }$ & $\sqrt{ }$ & $\sqrt{ }$ & $\sqrt{ }$ \\
\hline 3. & 100 & $\sqrt{ }$ & $\sqrt{ }$ & $\sqrt{ }$ & $\sqrt{ }$ & $\sqrt{ }$ & $\sqrt{ }$ & $\sqrt{ }$ & $\sqrt{ }$ & $\sqrt{ }$ & $\sqrt{ }$ \\
\hline 4. & 110 & $\sqrt{ }$ & $\sqrt{ }$ & $\sqrt{ }$ & $\mathrm{V}$ & $\sqrt{ }$ & $\sqrt{ }$ & $\sqrt{ }$ & $\sqrt{ }$ & $\sqrt{ }$ & $X$ \\
\hline 5. & 120 & $\sqrt{ }$ & $\sqrt{ }$ & $\sqrt{ }$ & $\sqrt{ }$ & $\sqrt{ }$ & $\sqrt{ }$ & $\sqrt{ }$ & $\sqrt{ }$ & $\mathrm{X}$ & $\sqrt{ }$ \\
\hline
\end{tabular}
success testing data from the auxiliary wristband. The data retrieval of the

\begin{tabular}{|c|c|c|c|c|c|c|c|c|c|c|c|}
\hline \multirow{2}{*}{ No. } & \multirow{2}{*}{ Distance } & \multicolumn{10}{|c|}{ Testing to - } \\
\hline & & 1 & 2 & 3 & 4 & 5 & 6 & 7 & 8 & 9 & 10 \\
\hline 1. & 80 & $\sqrt{ }$ & $\sqrt{ }$ & $\sqrt{ }$ & $\sqrt{ }$ & $\sqrt{ }$ & $\sqrt{ }$ & $\sqrt{ }$ & $\sqrt{ }$ & $\sqrt{ }$ & $\sqrt{ }$ \\
\hline 2. & 90 & $\sqrt{ }$ & $\sqrt{ }$ & $\sqrt{ }$ & $\sqrt{ }$ & $\sqrt{ }$ & $\sqrt{ }$ & $\sqrt{ }$ & $\sqrt{ }$ & $\sqrt{ }$ & $\sqrt{ }$ \\
\hline 3. & 100 & $\sqrt{ }$ & $\sqrt{ }$ & $\sqrt{ }$ & $\sqrt{ }$ & $\sqrt{ }$ & $\sqrt{ }$ & $\sqrt{ }$ & $\sqrt{ }$ & $\sqrt{ }$ & $\sqrt{ }$ \\
\hline 4. & 110 & $\sqrt{ }$ & $\sqrt{ }$ & $\sqrt{ }$ & $\sqrt{ }$ & $\sqrt{ }$ & $\sqrt{ }$ & $\sqrt{ }$ & $\sqrt{ }$ & $\sqrt{ }$ & $\sqrt{ }$ \\
\hline 5. & 120 & $\sqrt{ }$ & $\sqrt{ }$ & $\sqrt{ }$ & $\mathrm{V}$ & $\sqrt{ }$ & $\sqrt{ }$ & $\sqrt{ }$ & $\sqrt{ }$ & $\sqrt{ }$ & $\sqrt{ }$ \\
\hline
\end{tabular}
success testing tool is presented in the table below: :

Table 5 Test success with distance variation at angle $0^{\circ}$

Table 6 Test success with distance variation at angle $60^{\circ}$ 
Table 7 Test success with distance variation at angle $120^{\circ}$

\begin{tabular}{|c|c|c|c|c|c|c|c|c|c|c|c|}
\hline \multirow{2}{*}{ No. } & \multirow{2}{*}{ Distance } & \multicolumn{10}{|c|}{ Testing to - } \\
\cline { 3 - 15 } & & 1 & 2 & 3 & 4 & 5 & 6 & 7 & 8 & 9 & 10 \\
\hline 1. & 80 & $\sqrt{ }$ & $\sqrt{ }$ & $\sqrt{ }$ & $\sqrt{ }$ & $\sqrt{ }$ & $\sqrt{ }$ & $\sqrt{ }$ & $\sqrt{ }$ & $\sqrt{ }$ & $\sqrt{ }$ \\
\hline 2. & 90 & $\sqrt{ }$ & $\sqrt{ }$ & $\sqrt{ }$ & $\sqrt{ }$ & $\sqrt{ }$ & $\sqrt{ }$ & $\sqrt{ }$ & $\sqrt{ }$ & $\sqrt{ }$ & $\sqrt{ }$ \\
\hline 3. & 100 & $\sqrt{ }$ & $\sqrt{ }$ & $\sqrt{ }$ & $\sqrt{ }$ & $\sqrt{ }$ & $\sqrt{ }$ & $\sqrt{ }$ & $\sqrt{ }$ & $\sqrt{ }$ & $\sqrt{ }$ \\
\hline 4. & 110 & $\sqrt{ }$ & $\sqrt{ }$ & $\mathrm{X}$ & $\sqrt{ }$ & $\sqrt{ }$ & $\sqrt{ }$ & $\sqrt{ }$ & $\sqrt{ }$ & $\sqrt{ }$ & $\sqrt{ }$ \\
\hline 5. & 120 & $\sqrt{ }$ & $\sqrt{ }$ & $\sqrt{ }$ & $\sqrt{ }$ & $\sqrt{ }$ & $\mathrm{X}$ & $\sqrt{ }$ & $\sqrt{ }$ & $\sqrt{ }$ & $\sqrt{ }$ \\
\hline
\end{tabular}

Description :

- The tool successfully detects the presence of a marked object $(\sqrt{ })$

- The tool does not successfully detect the presence of a marked object (X)

Percentage Calculation of Success Rate

Success rate $=\frac{\text { Number of tools beeps }}{\text { The number of tests performed }} X 100 \%$

$$
\begin{aligned}
& =\frac{146}{150} \times 100 \% \\
& =97,33 \%
\end{aligned}
$$

\section{CONCLUSION}

Based on the results of the research and discussion, the following conclusions can be drawn:

A. This wristband as a walking aid for the visually impaired can detect the presence of repeatability objects by $98 \%$, as well as success in detecting the presence of obstacle objects by $97.33 \%$.

B. The nano arduino microcontroller is able to execute all three commands that the author has created as desired.

C. Wristbands as walking aids for the visually impaired were successfully made using nano arduino, HC-SR04 ultrasonic sensors, SG90 servo motors, and buzzers.

\section{THANK TO}

This opportunity the author tried to convey thanks to: A. Allah SWT who has given me a life
that is always good.
B. Both dear parents, Mr. Mokran (Alm) and Mrs. Mulyati thank you for your prayers, moral support and material.

C. My brother, Dian Eko, Moch. Fathoni and Tulus Priyanto who have given their support and encouragement.

D. Dean of Faculty of Engineering, PGRI Adi Buana University Surabaya Ibu Yunia Dwie Nurcahyanie, S.T., M.T.

E. Chairman of The Electrical Engineering Study Program Mr. Akbar Sujiwa, S.Si., M.Si.

F. Lecturer of Guidance Mr. Drs. Budi Prijo Sembodo, S.T., M.Kom.

G. All Lecturers and Staff in the Electrical Engineering Study Program of PGRI Adi Buana University Surabaya..

H. Friends - Compatry of the Electrical Engineering Study 


\section{BEST}

Journal of Applied Electrical and Science Technology - University of PGRI Adi Buana

p-ISSN 2715-2871

e-ISSN 2714-5247

Program faculty of Engineering, PGRI Adi Buana University Surabaya, especially the class of 2016 thanks for their cooperation and compatry.

\section{REFERENCES}

[1] Andreas, \& Wendanto, W. (2017). Tongkat Bantu Tunanetra Pendeteksi Halangan Menggunakan Sensor Ultrasonik Berbasis Mikrokontroler Arduino. Go Infotech: Jurnal Ilmiah STMIK. Vol .22 No.1, Juni 2016 : 24-30.

[2] Fergiyawan, Vicky Alvia, Dkk. 2018. Alat Pemandu Jalan untuk Penyandang Tunanetra Menggunakan Sensor Ultrasonic Berbasis Arduino. Seminar Nasional Teknologi Informasi dan Multimeida 2018. ISSN : 2302 - 3805. Universitas AMIKOM Yogyakarta, 10 Februari 2018.

[4] Morris, A., S., dan Langari, R. Measurement and Instrumentation Principles (3rded). Oxford: ButterworthHeinemann.
[5] Muhammad Nur Meizani, Dkk. 2015. Pembuatan Prototipe Kacamata Elektronikuntuk Tuna Netra Berbasis Mikrokontroler Menggunakan Sensor Ultrasonik. Jurnal Coding, Sistem Komputer Untan. Volume 03, No. 2 (2015), hal. 88-99. ISSN : 2338-493X.

[6] Nurhamidah, Dkk. 2016. Alat Bantu Navigasi Tunanetra Otomatis Menggunakan Sensor Ultrasonik Berbasis Arduino Uno. Program Studi Teknik Informatika Sekolah Tinggi Teknik Harapan Medan.

[7] Rochman, Sagita, and Akbar Sujiwa. "Peningkatan Daya Output Generator Listrik Tipe Afpmg Pada Putaran Rendah Menggunakan 3 Rotor Dan 2 Stator."

[8] Setyo, Dkk. 2016. Handsight : HandMounted Device untuk Membantu Tunanetra Berbasis Ultrasonik dan Arduino. Jurnal Teknologi dan Sistem Komputer. Vol. 3. No.1. Januari 2015 (eISSN: 2348-0403). 